\title{
Bioactive Surface Modification of Hydroxyapatite
}

\author{
Yasuhiko Abe, ${ }^{1}$ Yohei Okazaki, ${ }^{1}$ Kyou Hiasa, ${ }^{1}$ Keisuke Yasuda, ${ }^{1}$ Keisuke Nogami, ${ }^{1}$ \\ Wataru Mizumachi, ${ }^{1}$ and Isao Hirata ${ }^{2}$ \\ ${ }^{1}$ Department of Advanced Prosthodontics, Applied Life Sciences, Institute of Biomedical \& Health Sciences, Hiroshima University, \\ 1-2-3, Kasumi, Minami-ku, Hiroshima 734-8553, Japan \\ ${ }^{2}$ Department of Biomaterial Science, Basic Life Sciences, Institute of Biomedical \& Health Sciences, Hiroshima University, \\ 1-2-3, Kasumi, Minami-ku, Hiroshima 734-8553, Japan
}

Correspondence should be addressed to Yasuhiko Abe; abey@hiroshima-u.ac.jp

Received 2 April 2013; Accepted 20 May 2013

Academic Editor: Salvatore Sauro

Copyright (C) 2013 Yasuhiko Abe et al. This is an open access article distributed under the Creative Commons Attribution License, which permits unrestricted use, distribution, and reproduction in any medium, provided the original work is properly cited.

The purpose of this study was to establish an acid-etching procedure for altering the $\mathrm{Ca} / \mathrm{P}$ ratio of the nanostructured surface of hydroxyapatite (HAP) by using surface chemical and morphological analyses (XPS, XRD, SEM, surface roughness, and wettability) and to evaluate the in vitro response of osteoblast-like cells (MC3T3-E1 cells) to the modified surfaces. This study utilized HAP and HAP treated with $10 \%, 20 \%, 30 \%, 40 \%, 50 \%$, or $60 \%$ phosphoric acid solution for 10 minutes at $25^{\circ} \mathrm{C}$, followed by rinsing 3 times with ultrapure water. The $30 \%$ phosphoric acid etching process that provided a $\mathrm{Ca} / \mathrm{P}$ ratio of 1.50 , without destruction of the grain boundary of HAP, was selected as a surface-modification procedure. Additionally, HAP treated by the $30 \%$ phosphoric acid etching process was stored under dry conditions at $25^{\circ} \mathrm{C}$ for 12 hours, and the $\mathrm{Ca} / \mathrm{P}$ ratio approximated to 1.00 accidentally. The initial adhesion, proliferation, and differentiation (alkaline phosphatase (ALP) activity and relative mRNA level for ALP) of MC3T3-E1 cells on the modified surfaces were significantly promoted $(P<0.05$ and 0.01$)$. These findings show that the $30 \%$ phosphoric acid etching process for the nanostructured HAP surface can alter the $\mathrm{Ca} / \mathrm{P}$ ratio effectively and may accelerate the initial adhesion, proliferation, and differentiation of MC3T3-E1 cells.

\section{Introduction}

Hydroxyapatite $\left[\mathrm{Ca}_{10}\left(\mathrm{PO}_{4}\right)_{6}(\mathrm{OH})_{2}\right](\mathrm{HAP})$ and $\beta$-tricalcium phosphate $\left[\beta-\mathrm{Ca}_{3}\left(\mathrm{PO}_{4}\right)_{2}\right](\beta-\mathrm{TCP})$ are candidate materials for bone tissue engineering scaffolds because they have bioactive and osteoconductive properties in vivo [1]. These materials support the adhesion, proliferation, and differentiation of osteogenesis-related cells such as osteoblasts and mesenchymal stem cells. HAP is bioactive but not bioresorbable and is most thermodynamically stable at a physiological $\mathrm{pH}$ (7.4) [2]. In contrast, $\beta$-TCP has a high biodegradation rate but does not have the desired mechanical properties such as bending strength and fracture toughness [3]. Therefore, the biphasic calcium phosphate (BCP) concept is determined by the optimum balance between the more stable phase of HAP and the more soluble $\beta$-TCP. In vivo bioresorbability of BCP can be controlled by phase composition because the reactivity of $\mathrm{BCP}$ increases as the $\beta$-TCP/HAP ratio increases
$[4,5]$. Recently, bioactive glasses (BGs) were shown to exhibit especially high bioactivity by releasing dissolution ions such as $\mathrm{Ca}, \mathrm{P}$, and $\mathrm{Si}$, which may affect both gene expression and vascularization in osteogenic cells and, subsequently, promote a high rate of bone formation [6]. However, the exact mechanisms underlying the interaction between the ionic dissolution products of such BGs and human cells are not fully understood [1].

Presently, scaffolds fabricated from HAP that exhibit high porosity and pore interconnectivity are used clinically $[1,2,7$, $8]$. Thus, it is necessary to design a simple and reproducible approach for enhancing the bioactive surface of HAP by modifying the $\mathrm{Ca} / \mathrm{P}$ ratio of its nanostructured surface. A bioactive surface with a $\mathrm{Ca} / \mathrm{P}$ ratio of less than 1 is not suitable for implantation into the body because of its high solubility and acidity [2]; therefore, it had been proposed that the super surface layer of HAP $(\mathrm{Ca} / \mathrm{P}$ ratio $=1.67)$ should be modified to mimic that of $\beta$-TCP $(\mathrm{Ca} / \mathrm{P}$ ratio $=1.50)[9,10]$. 

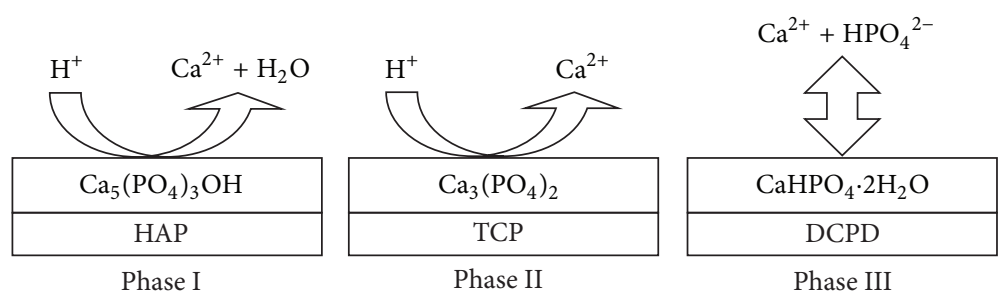

FIGURE 1: Modified schematic diagram representing the phenomena that occur on the surface of hydroxyapatite $\left(\mathrm{Ca}_{10}(\mathrm{PO})_{6}(\mathrm{OH})_{2}: \mathrm{HAP}\right)$ after implantation, illustrated by Bertazzo et al. [13]. Phase I: beginning of the implant procedure, where the solubilization of the HAP surface starts. Phase II: continuation of the solubilization of the HAP surface (tricalcium phosphate, $\mathrm{Ca}_{3}\left(\mathrm{PO}_{4}\right)_{2}$ : TCP). Phase III: achievement of equilibrium between physiological solutions and the modified surface of $\mathrm{HAP}$ (dicalcium phosphate dehydrate $\left(\right.$ brushite), $\mathrm{CaHPO}_{4} \cdot 2 \mathrm{H}_{2} \mathrm{O}$ : DCPD).

Dorozhkin $[11,12]$ illustrated the processes of solubilization, the equilibrium between the HAP surface and aqueous solutions, and the interaction between organisms and HAP surfaces very well. According to Dorozhkin, HAP dissolution occurs through 5 steps as follows:

(1) $\mathrm{Ca}_{5}\left(\mathrm{PO}_{4}\right)_{3} \mathrm{OH}_{(\mathrm{s})}+\mathrm{H}^{+}{ }_{(\mathrm{aq})} \rightleftarrows \mathrm{Ca}_{5}\left(\mathrm{PO}_{4}\right)_{3}\left(\mathrm{H}_{2} \mathrm{O}\right)^{+}{ }_{(\mathrm{s})}$

(2) $2 \mathrm{Ca}_{5}\left(\mathrm{PO}_{4}\right)_{3}\left(\mathrm{H}_{2} \mathrm{O}\right)^{+}{ }_{(\mathrm{s})} \rightleftarrows 3 \mathrm{Ca}_{3}\left(\mathrm{PO}_{4}\right)_{2(\mathrm{~s})}+\mathrm{Ca}^{2+}{ }_{(\mathrm{aq})}+$ $2 \mathrm{H}_{2} \mathrm{O}_{(\mathrm{aq})}$

(3) $\mathrm{Ca}_{3}\left(\mathrm{PO}_{4}\right)_{2(\mathrm{~s})}+2 \mathrm{H}^{+}{ }_{(\mathrm{aq})} \rightleftarrows \mathrm{Ca}^{2+}{ }_{(\mathrm{aq})}+2 \mathrm{CaHPO}_{4(\mathrm{~s})}$

(4) $\mathrm{CaHPO}_{4(\mathrm{~s})}+\mathrm{H}^{+}(\mathrm{aq}) \rightleftarrows \mathrm{Ca}_{(\mathrm{aq})}^{2+}+\mathrm{H}_{2} \mathrm{PO}_{4(\mathrm{aq})}^{-}$

(5) $\mathrm{CaHPO}_{4(\mathrm{~s})} \rightleftarrows \mathrm{Ca}^{2+}(\mathrm{aq})+\mathrm{HPO}_{4(\mathrm{aq})}^{2-}$

These 5 steps show that, throughout the process of HAP dissolution, the composition of the surface changes to $\mathrm{Ca}_{3}\left(\mathrm{PO}_{4}\right)_{2}$ (tricalcium phosphate, TCP) and $\mathrm{CaHPO}_{4}$ (dicalcium phosphate dehydrate, DCPD). Then, Bertazzo et al. [13] proposed 3 initial phases that occur before equilibrium is established between the HAP surface and biological fluids (Figure 1). With time, equilibrium is reached between the modified HAP surface and biological fluids, hence forming the compound DCPD on this surface (phase III in Figure 1). Following the achievement of equilibrium on the surface, there are steps that lead to the integration of the HAP surface with the tissue, such as protein adsorption and cell adhesion.

We put forth the hypothesis that the acid-etching procedure, altering the $\mathrm{Ca} / \mathrm{P}$ ratio of the HAP surface directly by phosphoric acid, that has been described in this study can cause the bioactive surfaces to mimic the initial phases proposed by Bertazzo et al. [13] because the sintering process for acquiring the desired surface of HAP is complex and unstable [2]. Therefore, the purpose of this study was to establish an acid-etching procedure for altering the $\mathrm{Ca} / \mathrm{P}$ ratio of the nanostructured surface of HAP by surface chemical and morphological analyses and to evaluate the in vitro response of osteoblast-like cells to the modified surfaces.

\section{Materials and Methods}

\subsection{Establishment of Surface Modification}

2.1.1. Sample Preparation. HAP plates (thickness, $2 \mathrm{~mm}$; width, $10 \mathrm{~mm}$; length, $10 \mathrm{~mm}$ ) (APP-101; Pentax, Tokyo,
Japan) were used in this study. HAP plates were treated with $10 \%, 20 \%, 30 \%, 40 \%, 50 \%$, or $60 \%$ phosphoric acid $\left[\mathrm{H}_{3} \mathrm{PO}_{4}\right]$ (lot no. T1949; Sigma-Aldrich Japan, Tokyo, Japan) solution for 10 minutes at $25^{\circ} \mathrm{C}$, followed by rinsing 3 times with ultrapure water (MilliQ water: $>18 \mathrm{M} \Omega \mathrm{cm}$ ) (HAP-10\% PA, HAP-20\% PA, HAP-30\% PA, HAP-40\% PA, HAP-50\% $\mathrm{PA}$, and $\mathrm{HAP}-60 \% \mathrm{PA})$.

2.1.2. X-Ray Photoelectron Spectroscopy (XPS) Analysis. HAP, HAP-10\% PA, HAP-20\% PA, HAP-30\% PA, HAP$40 \% \mathrm{PA}, \mathrm{HAP}-50 \% \mathrm{PA}$, and $\mathrm{HAP}-60 \% \mathrm{PA}$ plates were mounted individually onto stubs with insulating tape. The surfaces of the plates were chemically analyzed using an Xray photoelectron spectroscopy (XPS) instrument (AXIS-HS; Kratos, Manchester, UK). The measurements were performed in vacuo $\left(\leq 10^{-7} \mathrm{~Pa}\right)$ with $\mathrm{Al}-\mathrm{K} \alpha$ monochromatic X-rays at a source power of $150 \mathrm{~W}$. The AXIS-HS was equipped with an electron flood gun for charge compensation. Wide- and narrow-scan spectra were acquired at pass energies of 80 and $40 \mathrm{eV}$, respectively. Peak positions were calibrated by referencing a value of $284.6 \mathrm{eV}$ for the peaks corresponding to $\mathrm{C}-\mathrm{C}$ and $\mathrm{C}-\mathrm{H}$ in the $\mathrm{C} 1 \mathrm{~s}$ spectrum. After smoothing the narrow scans, a straight line (for $\mathrm{C} 1 \mathrm{~s}, \mathrm{O} 1 \mathrm{~s}, \mathrm{Ca} 2 \mathrm{p}$, and $\mathrm{P}$ $2 p)$ was applied in the quantification. The relative sensitivity factors used to calculate the atomic ratios from the peak area ratios were 0.278 for $\mathrm{C} 1 \mathrm{~s}, 0.780$ for $\mathrm{O} 1 \mathrm{~s}, 1.833$ for $\mathrm{Ca} 2 \mathrm{p}$, and 0.486 for $\mathrm{P} 2 \mathrm{p}$. Reproducibility was guaranteed by obtaining 10 measurements per experimental sample. The data were analyzed using one-way ANOVA and Tukey's test for multiple comparisons $(P<0.05)$.

2.1.3. X-Ray Diffraction (XRD) Analysis. The thin films of the HAP and HAP-30\% PA plates were analyzed using an XRD instrument (Ultima IV; Rigaku, Osaka, Japan). Samples were scanned with $\mathrm{Cu}-\mathrm{K} \alpha$ radiation at $40 \mathrm{kV}$ and $50 \mathrm{~mA}$ between 10 and $90(2 \theta)$ degrees at a step size of 0.04 degrees and a scan rate of 2 degrees/minute. The results were compared to the ICDD standard for HAP (no. 01-072-1243).

\subsection{Evaluation of Surface Modification}

2.2.1. Sample Preparation. A HAP-30\% PA plate that was stored under dry conditions at $25^{\circ} \mathrm{C}$ for 12 hours (HAP-30\% 
$\mathrm{PA}-12 \mathrm{~h}$ ) was added as a new sample. The surface characteristics of HAP, HAP $-30 \% \mathrm{PA}$, and HAP $-30 \% \mathrm{PA}-12 \mathrm{~h}$ were evaluated by the following methods.

2.2.2. XPS Depth Profiling Analysis. Samples were analyzed using an XPS instrument at incidence angles of 90, 75, 60, 45, 30, and 15 degrees. The measurements were obtained under the above-mentioned conditions. The data were analyzed using one-way ANOVA and Tukey's test for multiple comparisons $(P<0.05)$.

2.2.3. Scanning Electron Microscope (SEM) Observation, Surface Roughness, and Wettability. An SEM (VE-8800; Keyence, Osaka, Japan) was used to observe the surface topography of samples. The surface roughness $(\mathrm{Ra})$ of samples was determined using a confocal laser scanning microscope (VK-8500; Keyence, Osaka, Japan). The Ra value $(\mu \mathrm{m})$ was defined as the average value of 5 areas $(100 \mu \mathrm{m} \times 100 \mu \mathrm{m})$ with 9 measuring points. The wettability of sample surfaces was measured using a contact angle meter (Slmage mini; Excimer, Kanagawa, Japan) with the sessile drop method and 3.6 $\mu \mathrm{L}$ ultrapure water; Young's equation was used for data analysis. The data were analyzed using one-way ANOVA and Tukey's test for multiple comparisons $(P<0.05)$.

\subsubsection{Initial Adhesion and Proliferation of Osteoblast-Like} Cells. Osteoblast-like cells (MC3T3-E1 derivative cell lines of mouse calvaria (RIKEN BioResource Center, Tsukuba, Japan)) were cultured in Dulbecco's Modified Eagle Medium (D-MEM) (lot no. RNBB4045; Sigma-Aldrich Japan, Tokyo, Japan) containing 10\% fetal bovine serum (lot nos. F0926, 027K03911; Sigma-Aldrich Japan, Tokyo, Japan) and 1\% penicillin-streptomycin (lot nos. P0781, 060M0811; SigmaAldrich Japan, Tokyo, Japan) at $37^{\circ} \mathrm{C}$ in a humidified atmosphere of $5 \% \mathrm{CO}_{2}$. The medium was changed twice a week.

MC3T3-E1 cells $\left(1 \times 10^{4}\right)$ were seeded onto HAP, HAP$30 \% \mathrm{PA}$, and $\mathrm{HAP}-30 \% \mathrm{PA}-12 \mathrm{~h}$ plates sterilized by ultraviolet (UV) irradiation for 4 hours. The cells were incubated at $37^{\circ} \mathrm{C}$ and $5 \% \mathrm{CO}_{2}$. Initial cell adhesion was evaluated at 0.5 and 24 hours and cell proliferation at 1, 4, and 7 days. Cells were seeded on tissue culture plates and incubated as controls over each incubation period.

Initial cell adhesion and cell proliferation were analyzed by a Cell Counting Kit- 8 assay (Dojindo Laboratory, Kumamoto, Japan), a colorimetric assay that uses a tetrazolium salt, WST-8, to determine viable cell number. After each incubation period, the growth medium in each well was removed by aspiration and replaced with a mixture of WST8 and D-MEM in a 1:10 ratio. After 2 hours of incubation at $37^{\circ} \mathrm{C}$ and $5 \% \mathrm{CO}_{2}$, a $110 \mu \mathrm{L}$ aliquot of the mixture that reacted with viable cells was dispensed in each well $(n=5)$ of a 96-well microplate. The absorbance was read at $450 \mathrm{~nm}$ by using a microplate reader (model 550; Bio-Rad Japan, Tokyo, Japan). The data were analyzed using two-way ANOVA and Tukey's test for multiple comparisons $(P<0.05)$.

2.2.5. Cell Differentiation of Osteoblast-Like Cells. MC3T3-E1 cells $\left(10 \times 10^{4}\right)$ were seeded onto HAP, HAP-30\% PA, and
$\mathrm{HAP}-30 \% \mathrm{PA}-12 \mathrm{~h}$ plates as described previously. Alkaline phosphatase (ALP) activity was evaluated at 7, 14, and 21 days after obtaining a confluent cell monolayer. Real-time polymerase chain reaction (PCR) analysis of ALP was carried out at 14,21 , and 28 days after obtaining a confluent cell monolayer.

ALP activity was determined by the SensoLyte $p$ NPP secreted ALP reporter gene assay (AnaSpec Corporate Headquarters, San Jose, CA), which is optimized to detect placental ALP activity and uses $p$-nitrophenyl phosphate $(p N P P)$ as a colorimetric phosphatase substrate. After each incubation period, the growth medium in each well was removed by aspiration, and each well was rinsed twice with $1 \mathrm{~mL}$ of lysis buffer. A mixture $(1 \mathrm{~mL})$ of $10 \mathrm{~mL}$ lysis buffer and $20 \mu \mathrm{L}$ Triton X-100 was added to each well, the cells were scraped and suspended, and $1,000 \mu \mathrm{L}$ of the cell suspension was transferred to a new well and incubated at $37^{\circ} \mathrm{C}$ and $5 \% \mathrm{CO}_{2}$ for 10 minutes. An aliquot of the cell suspension $(300 \mu \mathrm{L})$ was then mixed with $300 \mu \mathrm{L}$ of the $p$ NPP reaction mixture in a separate well. After 60 minutes of incubation, $300 \mu \mathrm{L}$ of stop solution was added to the cell suspension, followed by shaking for 1 minute. A $150 \mu \mathrm{L}$ aliquot of the mixture was dispensed to each well $(n=5)$ in a 96-well microplate. The absorbance was read at $405 \mathrm{~nm}$ by using the microplate reader.

Total RNA was extracted using an RNeasy Mini Kit (Qiagen, Tokyo, Japan). The total RNA concentration was adjusted to $10 \mathrm{ng} / \mu \mathrm{L}$ by using a NanoDrop 1000 system (Thermo Fisher Scientific, Wilmington, USA). First-strand cDNA was synthesized from total RNA $(10 \mathrm{ng} / \mu \mathrm{L})$ by using a ReverTra Ace qPCR RT Kit (Toyobo, Osaka, Japan). For each gene, a cycle curve experiment was performed, and the optimal number of PCR cycles was selected according to the results. Real-time PCR analysis was performed for ALP and GAPDH (internal control). The sequences of the primers used in this analysis were as follows: forward, $5^{\prime}$-AGGGTGGACTACCTCTTAGGTCT-3' and reverse, $5^{\prime}$ TGGTCAATCCTGCCTCCTTCC- $3^{\prime}$ for ALP amplification; and forward, $5^{\prime}$-GCCAGCCTCGTCCCGTAG-3' and reverse, $5^{\prime}$-CAAATGGCAGCCCTGGTGAC-3' for GAPDH amplification. The primers were purchased from Sigma. The data were analyzed using two-way ANOVA and Tukey's test for multiple comparisons $(P<0.05)$.

\section{Results}

\subsection{Establishment of Surface Modification}

3.1.1. XPS Analysis. The XPS-determined binding energies $(\mathrm{eV})$ of Ca $2 \mathrm{p}, \mathrm{P} 2 \mathrm{p}$, and $\Delta(\mathrm{Ca} 2 \mathrm{p}, \mathrm{P} 2 \mathrm{p})$; atomic concentrations (at.\%); and $\mathrm{Ca} / \mathrm{P}$ ratios for HAP, HAP-10\% PA, HAP-20\% PA, HAP-30\% PA, HAP-40\% PA, HAP-50\% PA, and HAP- $60 \%$ PA are shown in Table 1 . As for the binding energies of $\Delta(\mathrm{Ca} 2 \mathrm{p}, \mathrm{P} 2 \mathrm{p})$, there were no significant differences among samples $(P>0.05)$. The XPS-determined $\mathrm{Ca} / \mathrm{P}$ ratio $(1.65 \pm 0.02)$ of HAP matched the theoretical value (1.67). The $\mathrm{Ca} / \mathrm{P}$ ratios for $\mathrm{HAP}-10 \% \mathrm{PA}, \mathrm{HAP}-20 \% \mathrm{PA}, \mathrm{HAP}-$ $30 \%$ PA, HAP-40\% PA, HAP-50\% PA, and HAP-60\% PA 


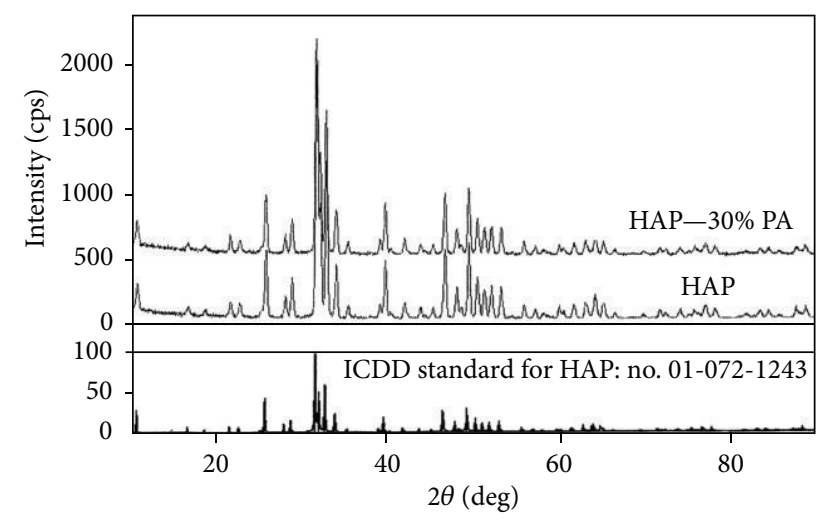

FIGURE 2: X-ray diffraction (XRD) spectra of HAP and HAP-30\% PA thin films referenced to the ICDD standard for HAP (no. 01-0721243). There was no difference between the XRD spectra of HAP and HAP-30\% PA, and the chemical composition of their thin films was assumed to be the same.

were significantly smaller than that for $\operatorname{HAP}(P<0.01)$. The $\mathrm{Ca} / \mathrm{P}$ ratio $(1.50 \pm 0.03)$ of $\mathrm{HAP}-30 \% \mathrm{PA}$ was the smallest and matched the theoretical value of TCP (1.50), although its value was not significantly different from that of HAP-20\% $\mathrm{PA}(P>0.05)$.

3.1.2. XRD Analysis. The XRD spectra of HAP and HAP$30 \%$ PA thin films, referenced to the ICDD standard for HAP (no. 01-072-1243), are shown in Figure 2. There was no difference between the XRD spectra of HAP and HAP-30\% $\mathrm{PA}$, and the chemical composition of their thin films was assumed to be the same.

\subsection{Evaluation of Surface Modification}

3.2.1. XPS Depth Profiling Analysis. The XPS-determined binding energies $(\mathrm{eV})$ of $\mathrm{Ca} 2 \mathrm{p}, \mathrm{P} 2 \mathrm{p}$, and $\Delta(\mathrm{Ca} 2 \mathrm{p}, \mathrm{P} 2 \mathrm{p})$ and the $\mathrm{Ca} / \mathrm{P}$ ratios for HAP, $\mathrm{HAP}-30 \% \mathrm{PA}$, and $\mathrm{HAP}-$ $30 \% \mathrm{PA}-12 \mathrm{~h}$ at each incidence angle of the $\mathrm{X}$-ray $(90,75$, $60,45,30$, or 15 degrees) are shown in Table 2 . The binding energy of $\Delta$ (Ca 2p, P 2p) of HAP-30\% PA-12 h (213.91 \pm 0.06 ) was significantly smaller than those of HAP and HAP$30 \%$ PA $(P<0.05)$, and there was no significant difference between the binding energies of HAP and HAP- $30 \%$ PA $(P>0.05)$. As for the $\mathrm{Ca} / \mathrm{P}$ ratios, there were significant differences among samples $(P<0.01)$, and the values of HAP, $\mathrm{HAP}-30 \% \mathrm{PA}$, and HAP $-30 \% \mathrm{PA}-12 \mathrm{~h}$ were $1.65 \pm 0.04$, $1.45 \pm 0.01$, and $1.09 \pm 0.02$, respectively. In each sample, changes in the binding energies and the $\mathrm{Ca} / \mathrm{P}$ ratios were not recognized by the different incidence angles of the X-ray.

\subsubsection{SEM, Surface Roughness, and Wettability. SEM images} for $\mathrm{HAP}, \mathrm{HAP}-30 \% \mathrm{PA}$, and $\mathrm{HAP}-30 \% \mathrm{PA}-12 \mathrm{~h}$ are shown in Figure 3. The traces with a lack of particles appeared at the surface of $\mathrm{HAP}-30 \% \mathrm{PA}$, and the more scabrous image was observed at the surface of HAP- $30 \%$ PA- $12 \mathrm{~h}$.

The surface roughness and wettability for HAP, HAP$30 \% \mathrm{PA}$, and HAP $-30 \% \mathrm{PA}-12 \mathrm{~h}$ are shown in Table 3. The surface roughness Ra value of $\mathrm{HAP}-30 \% \mathrm{PA}-12 \mathrm{~h}(0.96 \pm$ $0.04 \mu \mathrm{m}$ ) was significantly larger than the Ra values of HAP and HAP $-30 \%$ PA $(0.25 \pm 0.06 \mu \mathrm{m}$ and $0.91 \pm 0.05 \mu \mathrm{m}$, resp.; $P<0.01$ and 0.05 , resp.). The contact angle of HAP $-30 \%$ $\mathrm{PA}-12 \mathrm{~h}$ (13.67 \pm 3.54 degrees) was significantly smaller than the contact angles of HAP and HAP-30\% PA $(102.10 \pm 2.98$ degrees and $55.13 \pm 0.35$ degrees, resp.; $P<0.01$ ).

3.2.3. Initial Cell Adhesion and Proliferation. The initial cell adhesion of MC3T3-E1 cells to HAP, HAP-30\% PA, and HAP $-30 \%$ PA -12 h at 0.5 and 24 hours is shown in Figure 4. At 0.5 hours, the number of adherent cells for HAP-30\% $\mathrm{PA}-12 \mathrm{~h}$ was significantly higher than that for HAP $(P<$ $0.05)$. At 24 hours, the number of adherent cells for HAP$30 \% \mathrm{PA}-12 \mathrm{~h}$ was significantly higher than that for HAP $(P<0.01)$ and HAP $-30 \%$ PA $(P<0.05)$.

The proliferation of MC3T3-E1 cells on HAP, HAP- $30 \%$ $\mathrm{PA}$, and $\mathrm{HAP}-30 \% \mathrm{PA}-12 \mathrm{~h}$ at 1,4 , and 7 days is shown in Figure 5. At 4 and 7 days, cell proliferation on both HAP$30 \% \mathrm{PA}$ and $\mathrm{HAP}-30 \% \mathrm{PA}-12 \mathrm{~h}$ was significantly higher than that on HAP $(P<0.01)$; the difference between the growth on HAP $-30 \% \mathrm{PA}$ and HAP-30\% PA-12 h was not statistically significant $(P>0.05)$.

3.2.4. Cell Differentiation. The ALP activity of MC3T3-E1 cells on HAP, HAP $-30 \% \mathrm{PA}$, and HAP $-30 \% \mathrm{PA}-12 \mathrm{~h}$ at 7 , 14 , and 21 days after obtaining a confluent cell monolayer is shown in Figure 6. At 14 days, the ALP activity of the cells on $\mathrm{HAP}-30 \% \mathrm{PA}$ and HAP $-30 \% \mathrm{PA}-12 \mathrm{~h}$ was significantly higher than that on HAP $(P<0.01)$. The ALP activity at 14 days on HAP $-30 \% \mathrm{PA}-12 \mathrm{~h}$ was higher than that on HAP$30 \%$ PA, but the ALP activity at 21 days was lower than that on HAP- $30 \%$ PA. Although the ALP activities on HAP and HAP $-30 \%$ PA gradually increased from 7 to 21 days, the ALP activity on HAP $-30 \%$ PA- 12 h reached its peak at 14 days.

Relative mRNA levels for ALP in MC3T3-E1 cells on HAP, HAP $-30 \% \mathrm{PA}$, and HAP-30\% PA-12 h at 14,21 , and 28 days after obtaining a confluent cell monolayer are shown in Figure 7. At 14 days, there was no mRNA expression on HAP, but the expression on HAP $-30 \% \mathrm{PA}-12 \mathrm{~h}$ and HAP$30 \%$ PA was estimated in sequence. The expression on HAP was estimated at 21 days, and the expression on HAP, HAP$30 \% \mathrm{PA}$, and $\mathrm{HAP}-30 \% \mathrm{PA}-12 \mathrm{~h}$ was increased at 28 days. No statistically significant differences were observed in the expression at each time point $(P>0.05)$.

\section{Discussion}

4.1. Establishment of Surface Modification. Modification to the HAP surface by using etching with $10 \%, 20 \%, 30 \%, 40 \%$, $50 \%$, and $60 \%$ phosphoric acid altered the $\mathrm{Ca} / \mathrm{P}$ ratio from 1.50 to 1.58 . The $\mathrm{Ca} / \mathrm{P}$ ratio of $\mathrm{HAP}-30 \% \mathrm{PA}$ was the smallest and matched the theoretical value of TCP (1.50). However, there were no significant differences among the binding energies of $\Delta(\mathrm{Ca} 2 \mathrm{p}, \mathrm{P} 2 \mathrm{p})$ for all samples $(P>0.05)$. Since the $30 \%$ phosphoric acid etching process did not break the grain boundary of HAP and effectively brought the $\mathrm{Ca} / \mathrm{P}$ ratio 
TABLE 1: XPS-determined binding energies (eV) of Ca 2p, P 2p, and $\Delta(\mathrm{Ca} 2 \mathrm{p}, \mathrm{P} 2 \mathrm{p}$ ); atomic concentrations (at. \%); and Ca/P ratios for hydroxyapatite (HAP) and HAP treated with 10\%, 20\%, 30\%, 40\%, 50\%, or 60\% phosphoric acid (HAP-10\% PA, HAP-20\% PA, HAP-30\% PA, HAP- $40 \%$ PA, HAP- 50\% PA, and HAP-60\% PA).

\begin{tabular}{|c|c|c|c|c|c|c|c|c|c|}
\hline \multirow{2}{*}{ Sample } & & \multicolumn{3}{|c|}{ Binding energy $(\mathrm{eV})$} & \multicolumn{4}{|c|}{ At. $\%$} & \multirow{2}{*}{$\mathrm{Ca} / \mathrm{P}$} \\
\hline & & $\mathrm{Ca} 2 \mathrm{p}$ & P 2p & $\Delta(\mathrm{Ca} 2 \mathrm{p}, \mathrm{P} 2 \mathrm{p})$ & $\mathrm{C} 1 \mathrm{~s}$ & $\mathrm{O} 1 \mathrm{~s}$ & $\mathrm{Ca} 2 \mathrm{p}$ & P 2p & \\
\hline \multirow{2}{*}{ HAP } & Mean & 346.51 & 132.45 & $214.06^{\mathrm{a}}$ & 26.81 & 47.74 & 15.84 & 9.61 & 1.65 \\
\hline & SD & 0.03 & 0.05 & 0.05 & 2.02 & 1.35 & 0.50 & 0.31 & 0.02 \\
\hline \multirow{2}{*}{$\mathrm{HAP}-10 \% \mathrm{PA}$} & Mean & 346.87 & 132.80 & $214.07^{\mathrm{a}}$ & 11.04 & 58.00 & 18.80 & 12.17 & $1.54^{\mathrm{c}}$ \\
\hline & $\mathrm{SD}$ & 0.05 & 0.05 & 0.05 & 1.06 & 0.58 & 0.34 & 0.18 & 0.01 \\
\hline \multirow{2}{*}{$\mathrm{HAP}-20 \%$ PA } & Mean & 346.77 & 132.72 & $214.05^{\mathrm{a}}$ & 15.70 & 54.75 & 17.77 & 11.78 & $1.51^{\mathrm{b}}$ \\
\hline & $\mathrm{SD}$ & 0.09 & 0.09 & 0.05 & 6.12 & 3.76 & 1.52 & 0.84 & 0.02 \\
\hline \multirow{2}{*}{$\mathrm{HAP}-30 \%$ PA } & Mean & 346.61 & 132.54 & $214.07^{\mathrm{a}}$ & 25.80 & 49.32 & 14.92 & 9.96 & $1.50^{\mathrm{b}}$ \\
\hline & $\mathrm{SD}$ & 0.06 & 0.07 & 0.05 & 1.09 & 1.36 & 0.58 & 0.54 & 0.03 \\
\hline \multirow{2}{*}{$\mathrm{HAP}-40 \% \mathrm{PA}$} & Mean & 346.85 & 132.79 & $214.06^{\mathrm{a}}$ & 9.94 & 57.77 & 19.66 & 12.63 & $1.56^{\mathrm{c}, \mathrm{d}}$ \\
\hline & $\mathrm{SD}$ & 0.05 & 0.07 & 0.05 & 0.83 & 0.61 & 0.18 & 0.11 & 0.02 \\
\hline \multirow{2}{*}{$\mathrm{HAP}-50 \% \mathrm{PA}$} & Mean & 346.91 & 132.88 & $214.03^{\mathrm{a}}$ & 11.10 & 57.48 & 19.19 & 12.24 & $1.57^{\mathrm{c}, \mathrm{d}}$ \\
\hline & $\mathrm{SD}$ & 0.07 & 0.08 & 0.05 & 1.80 & 1.10 & 0.56 & 0.25 & 0.04 \\
\hline \multirow{2}{*}{$\mathrm{HAP}-60 \% \mathrm{PA}$} & Mean & 346.73 & 132.68 & $214.05^{\mathrm{a}}$ & 10.93 & 57.78 & 19.18 & 12.11 & $1.58^{\mathrm{d}}$ \\
\hline & $\mathrm{SD}$ & 0.05 & 0.04 & 0.05 & 0.32 & 0.26 & 0.12 & 0.12 & 0.02 \\
\hline
\end{tabular}

The presence of the same superscript letter for the values indicates that there were no significant differences among the samples $(P>0.05)$.

TABLE 2: XPS-determined binding energies (eV) of Ca 2p, P 2p, and $\Delta(\mathrm{Ca} 2 \mathrm{p}, \mathrm{P} 2 \mathrm{p}$ ), and $\mathrm{Ca} / \mathrm{P}$ ratios for hydroxyapatite (HAP), HAP treated with $30 \%$ phosphoric acid (HAP-30\% PA), and HAP-30\% PA in storage for 12 hours (HAP-30\% PA-12 h) at each incidence angle of the $\mathrm{X}$-ray $(90,75,60,45,30$, or 15 degrees).

\begin{tabular}{|c|c|c|c|c|c|}
\hline \multirow{2}{*}{ Sample } & \multirow{2}{*}{ Angle of incidence (degrees) } & \multicolumn{3}{|c|}{ Binding energy $(\mathrm{eV})$} & \multirow{2}{*}{$\mathrm{Ca} / \mathrm{P}$} \\
\hline & & $\mathrm{Ca} 2 \mathrm{p}$ & P 2p & $\Delta($ Ca $2 p$, P 2p $)$ & \\
\hline \multirow{8}{*}{ HAP } & 90 & 346.60 & 132.55 & 214.05 & 1.65 \\
\hline & 75 & 346.70 & 132.60 & 214.10 & 1.59 \\
\hline & 60 & 346.60 & 132.50 & 214.10 & 1.63 \\
\hline & 45 & 346.65 & 132.55 & 214.10 & 1.66 \\
\hline & 30 & 346.60 & 132.50 & 214.10 & 1.69 \\
\hline & 15 & 346.60 & 132.55 & 214.05 & 1.68 \\
\hline & Mean & 346.63 & 132.54 & $214.08^{\mathrm{a}}$ & $1.65^{\mathrm{b}}$ \\
\hline & SD & 0.04 & 0.04 & 0.03 & 0.04 \\
\hline \multirow{8}{*}{$\mathrm{HAP}-30 \%$ PA } & 90 & 346.80 & 132.75 & 214.05 & 1.45 \\
\hline & 75 & 346.80 & 132.75 & 214.05 & 1.44 \\
\hline & 60 & 346.85 & 132.75 & 214.10 & 1.45 \\
\hline & 45 & 346.85 & 132.80 & 214.05 & 1.44 \\
\hline & 30 & 346.90 & 132.95 & 213.95 & 1.46 \\
\hline & 15 & 346.90 & 132.65 & 214.25 & 1.45 \\
\hline & Mean & 346.85 & 132.78 & $214.08^{\mathrm{a}}$ & $1.45^{\mathrm{b}}$ \\
\hline & SD & 0.04 & 0.10 & 0.10 & 0.01 \\
\hline \multirow{8}{*}{$\mathrm{HAP}-30 \% \mathrm{PA}-12 \mathrm{~h}$} & 90 & 347.30 & 133.40 & 213.90 & 1.11 \\
\hline & 75 & 347.25 & 133.40 & 213.85 & 1.10 \\
\hline & 60 & 347.30 & 133.45 & 213.85 & 1.10 \\
\hline & 45 & 347.30 & 133.40 & 213.90 & 1.09 \\
\hline & 30 & 347.30 & 133.35 & 213.95 & 1.11 \\
\hline & 15 & 347.30 & 133.30 & 214.00 & 1.06 \\
\hline & Mean & 347.29 & 133.38 & 213.91 & $1.09^{\mathrm{b}}$ \\
\hline & SD & 0.02 & 0.05 & 0.06 & 0.02 \\
\hline
\end{tabular}

${ }^{\mathrm{a}} P>0.05$ indicates no significant difference between the samples.

${ }^{\mathrm{b}} P<0.01$ indicates significant differences among the samples. 


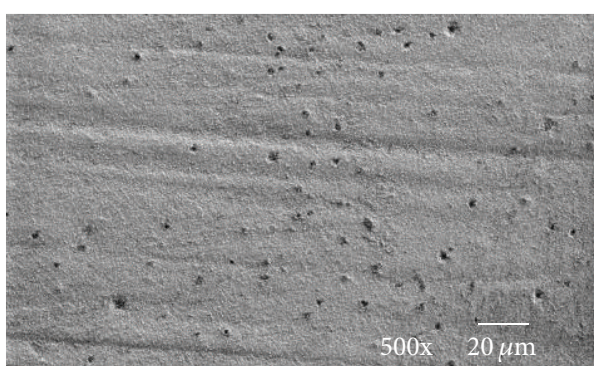

(a)

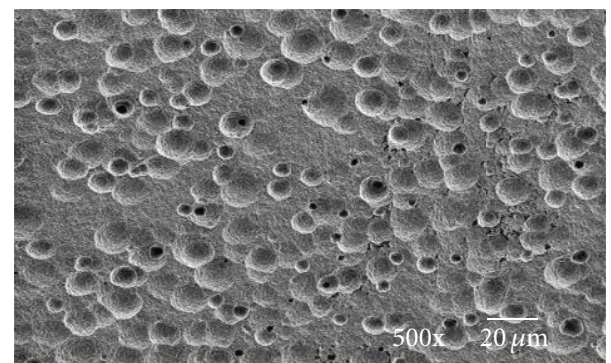

(b)

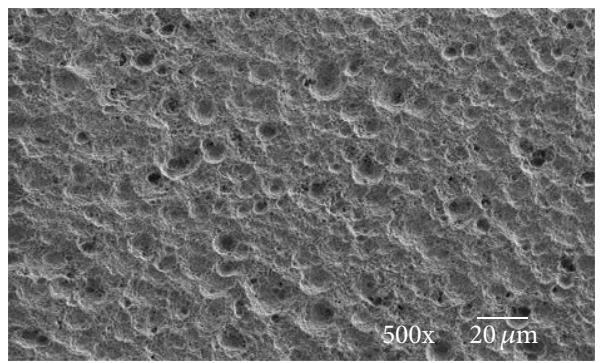

(c)

Figure 3: SEM images of (a) HAP, (b) HAP-30\% PA, and (c) HAP-30\% PA-12 h.

TABLE 3: Surface roughness and wettability for HAP, HAP-30\% PA, and $\mathrm{HAP}-30 \% \mathrm{PA}-12 \mathrm{~h}$.

\begin{tabular}{lccc}
\hline Sample & & $\begin{array}{c}\text { Surface roughness } \\
\mathrm{Ra}(\mu \mathrm{m})\end{array}$ & $\begin{array}{c}\text { Wettability } \\
\text { Contact angle } \\
\text { (degrees) }\end{array}$ \\
\hline HAP & Mean & 0.25 & $102.10^{\mathrm{c}}$ \\
& SD & 0.06 & 2.98 \\
HAP_30\% PA & Mean & $0.91^{\mathrm{a}}$ & $55.13^{\mathrm{c}}$ \\
& $\mathrm{SD}$ & 0.05 & 0.35 \\
HAP_30\% PA-12 h & Mean & $0.96^{\mathrm{a}, \mathrm{b}}$ & $13.67^{\mathrm{c}}$ \\
& SD & 0.04 & 3.54 \\
\hline
\end{tabular}

Surface roughness: ${ }^{\mathrm{a}} P<0.01$ indicates significant difference from HAP. ${ }^{\mathrm{b}} P<0.05$ indicates significant difference from HAP-30\% PA.

Wettability: ${ }^{\mathrm{c}} P<0.01$ indicates significant differences among the samples.

to 1.50 , this process was selected as a surface-modification procedure.

XRD analysis showed that the chemical composition of the thin films (a level of $100 \mathrm{~nm}$ ) for HAP and HAP-30\% PA was assumed to be the same. This finding does not illustrate that the changed $\mathrm{Ca} / \mathrm{P}$ ratio leads to alteration of the chemical composition of the surface. Thus, the nanostructured surface of $\mathrm{HAP}-30 \% \mathrm{PA}$ has not yet been confirmed as being modified to $\mathrm{TCP}$, although the $\mathrm{Ca} / \mathrm{P}$ ratio was 1.50 .

4.2. Evaluation of Surface Modification. The $\mathrm{Ca} / \mathrm{P}$ ratio of $\mathrm{HAP}-30 \% \mathrm{PA}-12 \mathrm{~h}$ was approximated to the $\mathrm{Ca} / \mathrm{P}$ ratio of DCPD (1.00), but this finding was obtained accidentally. The XPS depth profiling analyses for HAP, HAP-30\% PA, and $\mathrm{HAP}-30 \% \mathrm{PA}-12 \mathrm{~h}$ were performed to evaluate the chemical compositions of their nanostructured surfaces. The

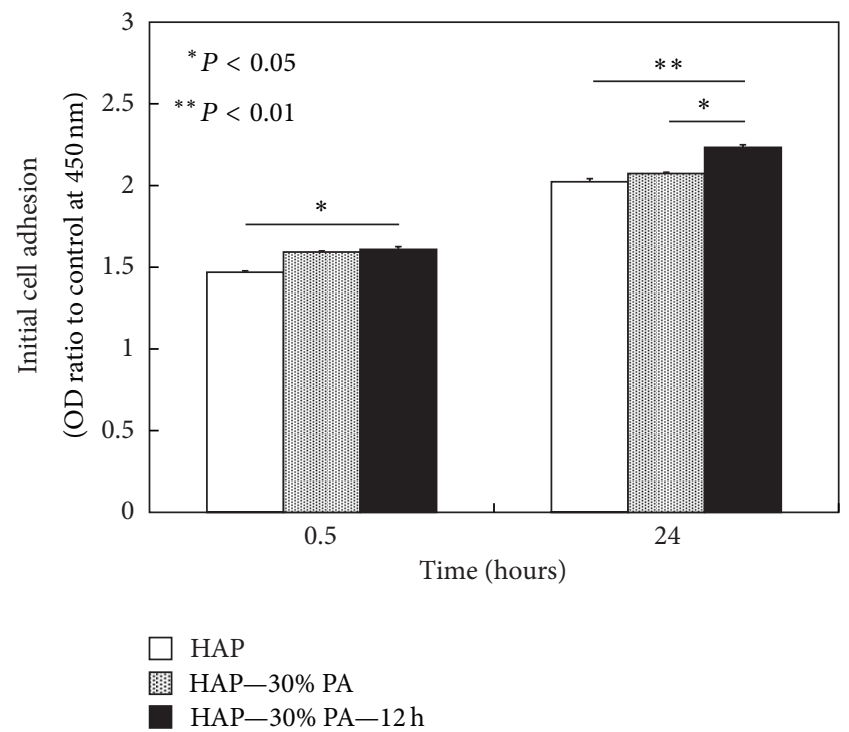

FIGURE 4: Initial cell adhesion of MC3T3-E1 osteoblast-like cells to HAP, HAP $-30 \% \mathrm{PA}$, and HAP-30\% $\mathrm{PA}-12 \mathrm{~h}$ at 0.5 and 24 hours. At 0.5 hours, the number of cells adherent to HAP- $30 \%$ $\mathrm{PA}-12 \mathrm{~h}$ was significantly greater than that for HAP $(P<0.05)$. At 24 hours, the number of cells adherent to HAP-30\% PA-12 h was significantly greater than those for both HAP $(P<0.01)$ and HAP- $30 \%$ PA $(P<0.05)$.

binding energy of $\Delta(\mathrm{Ca} 2 \mathrm{p}, \mathrm{P} 2 \mathrm{p})$ of HAP- $30 \%$ PA $-12 \mathrm{~h}$ was significantly smaller than that of HAP and HAP- $30 \%$ PA $(P<0.05)$. The $\mathrm{Ca} / \mathrm{P}$ ratio of $\mathrm{HAP}-30 \% \mathrm{PA}-12 \mathrm{~h}$ (1.09) was significantly smaller than that of HAP-30\% PA $(1.50)(P<0.01)$. The SEM results showed a greater degree 

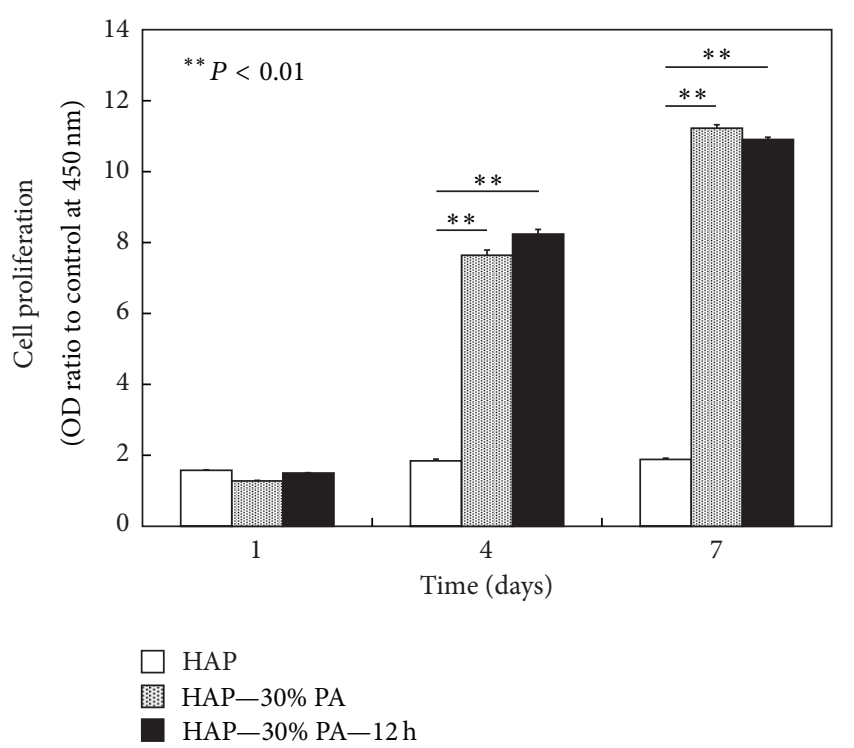

FIGURE 5: Cell proliferation of MC3T3-E1 osteoblast-like cells on HAP, HAP $-30 \%$ PA, and HAP-30\% PA $-12 \mathrm{~h}$ at 1,4 , and 7 days. At 4 and 7 days, cell proliferation on $\mathrm{HAP}-30 \% \mathrm{PA}$ and $\mathrm{HAP}-30 \%$ $\mathrm{PA}-12 \mathrm{~h}$ was significantly higher than that on $\operatorname{HAP}(P<0.01)$; the difference in the cell proliferation on $\mathrm{HAP}-30 \% \mathrm{PA}$ and $\mathrm{HAP}-30 \%$ $\mathrm{PA}-12 \mathrm{~h}$ was not statistically different $(P>0.05)$.

of scabrousness at the surface of HAP- $30 \% \mathrm{PA}-12 \mathrm{~h}$ than HAP- $30 \%$ PA.

The reasons for reduction of the $\mathrm{Ca} / \mathrm{P}$ ratio of the modified surface were (i) Ca defect and (ii) $\mathrm{P}$ abundance. $\mathrm{P}$ abundance could not be considered because the surface treated with $30 \%$ phosphoric acid solution was rinsed with ultrapure water, and the expansion of the break of the grain boundary of HAP was not observed in the SEM image of $\mathrm{HAP}-30 \% \mathrm{PA}-12 \mathrm{~h}$. The $30 \%$ phosphoric acid etching process promotes decalcification of the surface, resulting in the reduction of the $\mathrm{Ca} / \mathrm{P}$ ratio by $\mathrm{Ca}$ defects. As for the reduction of the $\mathrm{Ca} / \mathrm{P}$ ratio of $\mathrm{HAP}-30 \% \mathrm{PA}-12 \mathrm{~h}$ to 1.00 , it is believed that the $\mathrm{Ca}$ in the outer layer of the nanostructured surface is supplied to the deep layer for 12 hours to equilibrate the amorphous calcium phosphate.

Reduction in the $\mathrm{Ca} / \mathrm{P}$ ratio leads to high solubility of the surface. Additionally, surface modification induces the rougher and wetter surface of HAP. Generally, a contact angle of more than 65 degrees indicates a hydrophobic surface, and a contact angle of less than 65 degrees indicates a hydrophilic surface. Since the contact angle of HAP (102.10 degrees) is greater than 65 degrees, the hydrophobic surface becomes more intense with an increase in surface roughness. However, in this study, the contact angle grew smaller with an increase in surface roughness, resulting in a super hydrophilic surface. These findings demonstrate that the surface might have been modified both morphometrically and chemically.

We expected that the in vitro responses of osteoblastlike cells to HAP-30\% PA and HAP-30\% PA-12 h would

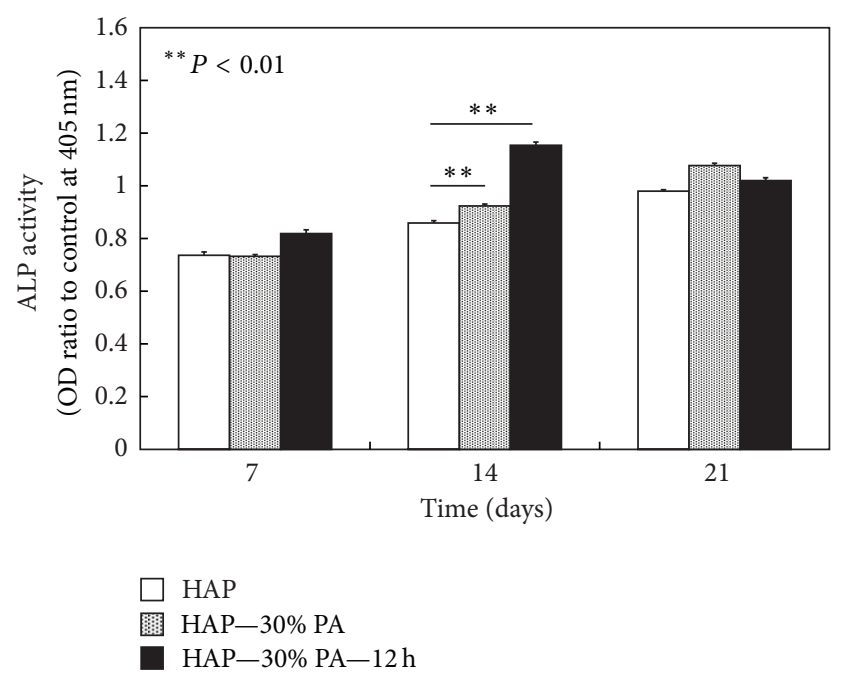

FIGURE 6: ALP activities of MC3T3-E1 osteoblast-like cells on HAP, $\mathrm{HAP}-30 \% \mathrm{PA}$, and $\mathrm{HAP}-30 \% \mathrm{PA}-12 \mathrm{~h}$ at 7,14 , and 21 days after obtaining a confluent cell monolayer. At 14 days, the ALP activities of the cells on HAP-30\% PA and HAP-30\% PA-12 h were significantly higher than that on HAP $(P<0.01)$. The ALP activity at 14 days for HAP-30\% $\mathrm{PA}-12 \mathrm{~h}$ was higher than that for HAP-30\% PA, but the ALP activity at 21 days was lower than that for HAP - 30\% PA. Although the ALP activities for HAP and HAP$30 \%$ PA gradually increased from 7 to 21 days, the ALP activity for $\mathrm{HAP}-30 \% \mathrm{PA}-12 \mathrm{~h}$ reached its peak at 14 days.

be better than those to HAP since the high biodegradation rate of TCP should improve early cell attachment [14, 15]. During initial cell adhesion, HAP-30\% PA and HAP-30\% $\mathrm{PA}-12 \mathrm{~h}$ were superior to HAP. Cell proliferation on HAP$30 \% \mathrm{PA}$ and $\mathrm{HAP}-30 \% \mathrm{PA}-12 \mathrm{~h}$ was 4 times higher at 4 days and 6 times higher at 7 days than that on HAP; these differences were statistically significant $(P<0.01$ for both). MC3T3-E1 cells reached a proliferation peak around day 7 on all substrates, and the cell differentiation process is reflected by ALP activity [16, 17]. The ALP activities at 14 days on $\mathrm{HAP}-30 \% \mathrm{PA}$ and $\mathrm{HAP}-30 \% \mathrm{PA}-12 \mathrm{~h}$ were significantly higher than that on HAP $(P<0.01)$ and, in particular, the ALP activity on HAP $-30 \% \mathrm{PA}-12 \mathrm{~h}$ reached its peak (at 14 days) faster than that on HAP and HAP$30 \%$ PA. Moreover, at 14 days, the mRNA expression on HAP $-30 \% \mathrm{PA}-12 \mathrm{~h}$ and HAP-30\% PA was estimated in sequence, but there was no expression on HAP. Intracellular signal transduction during the initial adhesion stage might play a crucial role in cell differentiation and mineralization on calcium phosphate-related biomaterials [14]. Therefore, these findings demonstrate the usefulness of HAP-30\% PA and $\mathrm{HAP}-30 \% \mathrm{PA}-12 \mathrm{~h}$ by the $30 \%$ phosphoric acid etching process to effectively alter the $\mathrm{Ca} / \mathrm{P}$ ratio. The hypothesis suggested in this study is supported by our evidence in acquiring bioactive surfaces, but the surface treated with $30 \%$ phosphoric acid solution has not yet been confirmed to be modified to TCP or DCPD in the initial phases proposed by Bertazzo et al. [13]. 


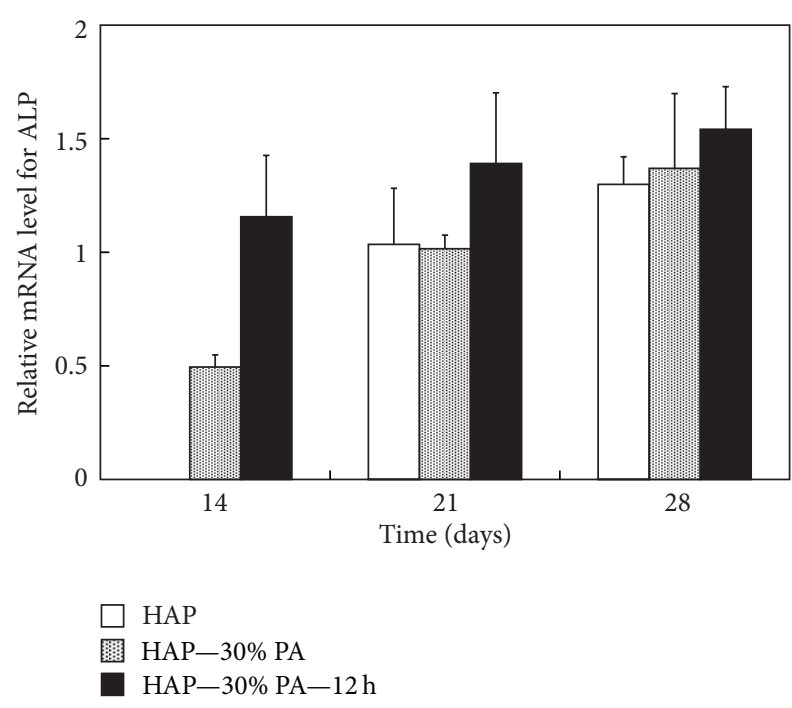

FIGURE 7: Relative mRNA levels for ALP in MC3T3-E1 osteoblastlike cells on HAP, HAP- $30 \%$ PA, and HAP $-30 \%$ PA $-12 \mathrm{~h}$ at 14 , 21 , and 28 days after obtaining a confluent cell monolayer. At 14 days, there was no mRNA expression on HAP, but the expression on $\mathrm{HAP}-30 \% \mathrm{PA}-12 \mathrm{~h}$ and $\mathrm{HAP}-30 \%$ PA was estimated in sequence. At 21 days, the expression of ALP on HAP was estimated, and the expression on HAP, HAP-30\% PA, and HAP-30\% PA- $12 \mathrm{~h}$ was increased at 28 days. There were no statistically significant differences among expressions at any time $(P>0.05)$.

Furthermore, we will investigate the response of osteoclasts to HAP-30\% PA and HAP-30\% PA-12 h because osteoclasts regulating bone metabolism are coupled with osteoblasts in a direct or indirect manner in vivo and involve bone resorption and calcium release.

\section{Conclusions}

In this study, we established the acid-etching procedure to alter the $\mathrm{Ca} / \mathrm{P}$ ratio of the nanostructured surface of HAP by surface chemical and morphological analyses and evaluated the in vitro response of MC3T3-E1 osteoblast-like cells to the modified surfaces. The $30 \%$ phosphoric acid etching process for obtaining a $\mathrm{Ca} / \mathrm{P}$ ratio of 1.50 , without destruction of the grain boundary of HAP, was selected as a surfacemodification procedure. Additionally, HAP was treated with $30 \%$ phosphoric acid solution and stored under dry conditions at $25^{\circ} \mathrm{C}$ for 12 hours, and the $\mathrm{Ca} / \mathrm{P}$ ratio approximated to 1.00 accidentally. The acid-etching procedure for HAP significantly promoted the initial adhesion, proliferation, and differentiation of MC3T3-E1 cells. In future studies, the $\mathrm{Ca} / \mathrm{P}$ ratio of HAP scaffolds used clinically will be modified, and the usefulness of the scaffolds will be evaluated by in vivo studies.

\section{Conflict of Interests}

For a SensoLyte $p$ NPP secreted ALP reporter gene assay (AnaSpec Corporate Headquarters, San Jose, CA), and a ReverTra Ace qPCR RT Kit (Toyobo, Osaka, Japan), there is no conflict of interests to declare.

\section{Acknowledgments}

This study was supported in part by a Grant-in-Aid for Scientific Research (nos. 21592452 and 24592915) from the Japan Society for the Promotion of Science (JSPS) and the Ministry of Education, Culture, Sports, Science and Technology (MEXT), Japan (2009-2011 and 2012-2014). The authors would like to thank Editage for providing editorial assistance.

\section{References}

[1] A. Hoppe, N. S. Güldal, and A. R. Boccaccini, "A review of the biological response to ionic dissolution products from bioactive glasses and glass-ceramics," Biomaterials, vol. 32, no. 11, pp. 2757-2774, 2011.

[2] S. V. Dorozhkin, "Bioceramics of calcium orthophosphates," Biomaterials, vol. 31, no. 7, pp. 1465-1485, 2010.

[3] S. Cai, G. H. Xu, X. Z. Yu, W. J. Zhang, Z. Y. Xiao, and K. D. Yao, "Fabrication and biological characteristics of $\beta$ tricalcium phosphate porous ceramic scaffolds reinforced with calcium phosphate glass," Journal of Materials Science: Materials in Medicine, vol. 20, no. 1, pp. 351-358, 2009.

[4] G. Daculsi, O. Laboux, O. Malard, and P. Weiss, "Current state of the art of biphasic calcium phosphate bioceramics," Journal of Materials Science: Materials in Medicine, vol. 14, no. 3, pp. 195200, 2003.

[5] S. Kannan, S. I. Vieira, S. M. Olhero et al., "Synthesis, mechanical and biological characterization of ionic doped carbonated hydroxyapatite/ $\beta$-tricalcium phosphate mixtures," Acta Biomaterialia, vol. 7, no. 4, pp. 1835-1843, 2011.

[6] H. Yun, J. Park, S. Kim, Y. Kim, and J. Jang, "Effect of the pore structure of bioactive glass balls on biocompatibility in vitro and in vivo," Acta Biomaterialia, vol. 7, no. 6, pp. 2651-2660, 2011.

[7] Y. Ito, N. Tanaka, Y. Fujimoto et al., "Bone formation using novel interconnected porous calcium hydroxyapatite ceramic hybridized with cultured marrow stromal stem cells derived from Green rat," Journal of Biomedical Materials Research A, vol. 69, no. 3, pp. 454-461, 2004.

[8] K. Morita, K. Doi, T. Kubo et al., "Enhanced initial bone regeneration with inorganic polyphosphate-adsorbed hydroxyapatite," Acta Biomaterialia, vol. 6, no. 7, pp. 2808-2815, 2010.

[9] D. Olton, J. Li, M. E. Wilson et al., "Nanostructured calcium phosphates (NanoCaPs) for non-viral gene delivery: influence of the synthesis parameters on transfection efficiency," Biomaterials, vol. 28, no. 6, pp. 1267-1279, 2007.

[10] S. Meng, Z. Zhang, and M. Rouabhia, "Accelerated osteoblast mineralization on a conductive substrate by multiple electrical stimulation," Journal of Bone and Mineral Metabolism, vol. 29, no. 5, pp. 535-544, 2011.

[11] S. V. Dorozhkin, "Surface reactions of apatite dissolution," Journal of Colloid and Interface Science, vol. 191, no. 2, pp. 489497, 1997.

[12] S. V. Dorozhkin, "Inorganic chemistry of the dissolution phenomenon: the dissolution mechanism of calcium apatites at the atomic (ionic) level," Comments on Inorganic Chemistry, vol. 20, no. 4-6, pp. 285-299, 1999.

[13] S. Bertazzo, W. F. Zambuzzi, D. D. P. Campos, T. L. Ogeda, C. V. Ferreira, and C. A. Bertran, "Hydroxyapatite surface solubility and effect on cell adhesion," Colloids and Surfaces B, vol. 78, no. 2, pp. 177-184, 2010. 
[14] K. Gellynck, E. A. Abou Neel, H. Li et al., "Cell attachment and response to photocured, degradable bone adhesives containing tricalcium phosphate and purmorphamine," Acta Biomaterialia, vol. 7, no. 6, pp. 2672-2677, 2011.

[15] Y. Tanimoto, Y. Shibata, Y. Kataoka, T. Miyazaki, and N. Nishiyama, "Osteoblast-like cell proliferation on tape-cast and sintered tricalcium phosphate sheets," Acta Biomaterialia, vol. 4, no. 2, pp. 397-402, 2008.

[16] H. Sowa, H. Kaji, T. Yamaguchi, T. Sugimoto, and K. Chihara, "Smad3 promotes alkaline phosphatase activity and mineralization of osteoblastic MC3T3-E1 cells," Journal of Bone and Mineral Research, vol. 17, no. 7, pp. 1190-1199, 2002.

[17] S. Sista, C. Wen, P. D. Hodgson, and G. Pande, “The influence of surface energy of titanium-zirconium alloy on osteoblast cell functions in vitro," Journal of Biomedical Materials Research A, vol. 97, no. 1, pp. 27-36, 2011. 

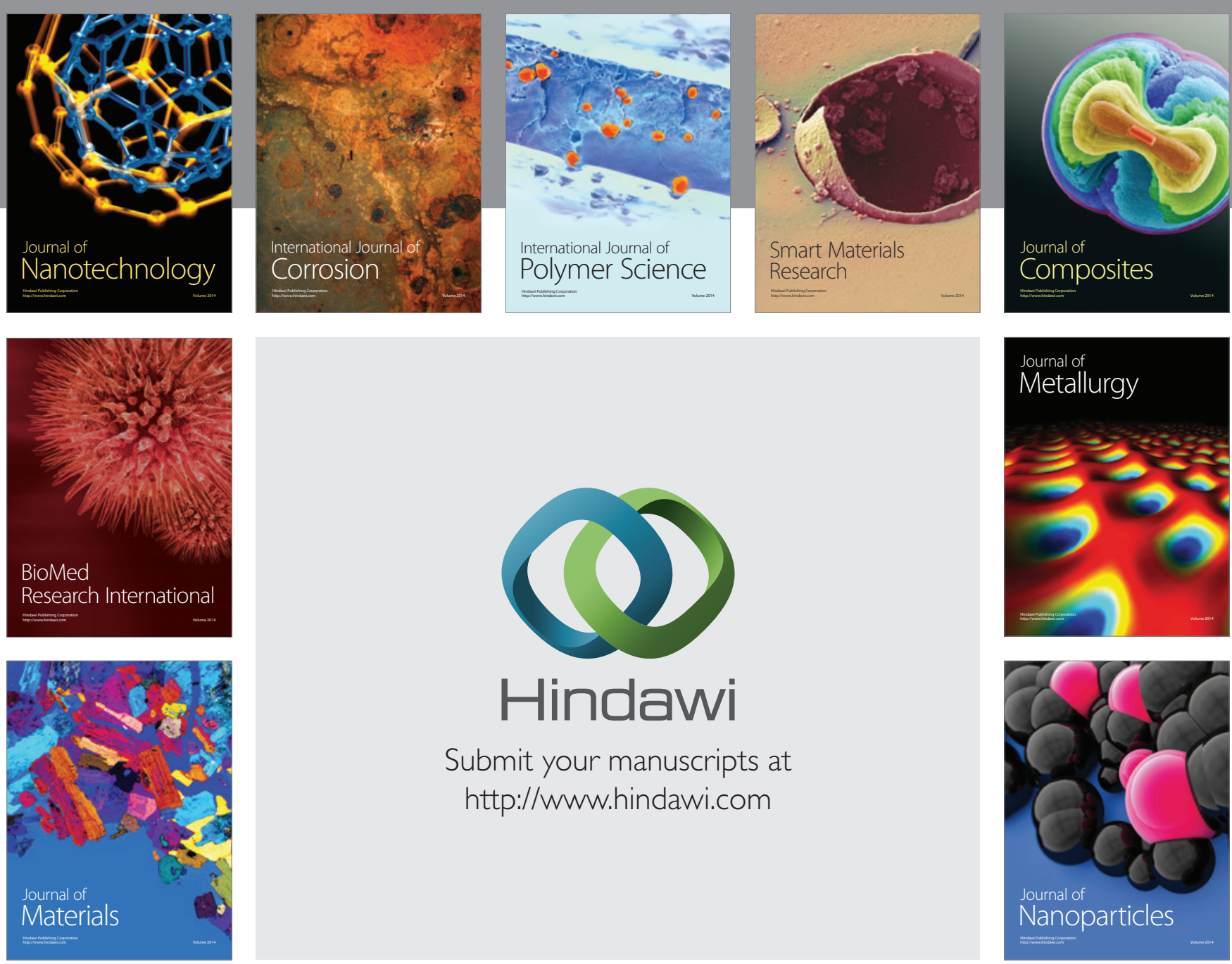

Submit your manuscripts at http://www.hindawi.com
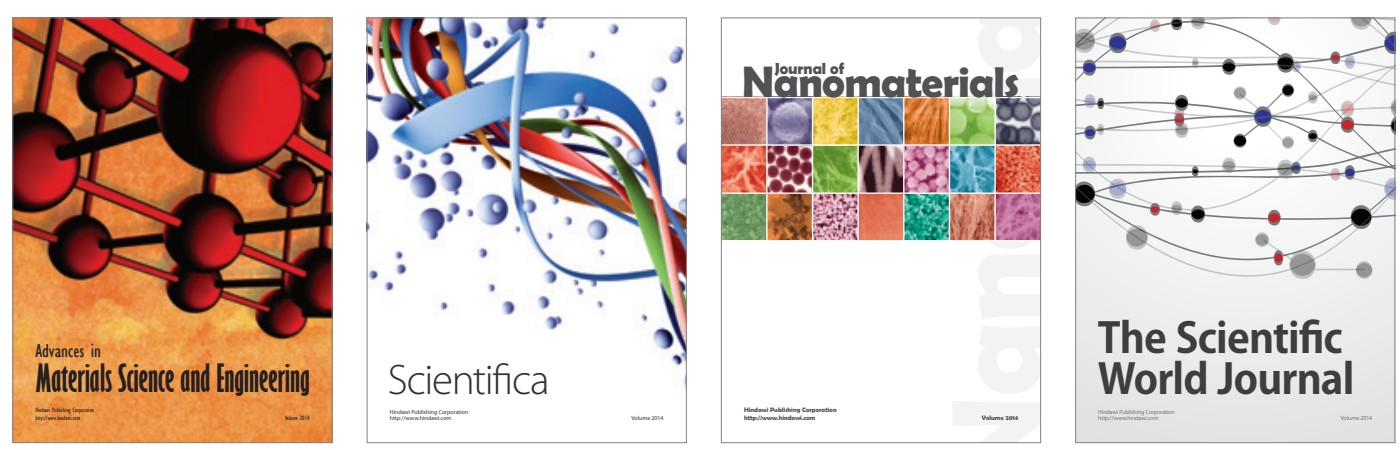

\section{The Scientific World Journal}
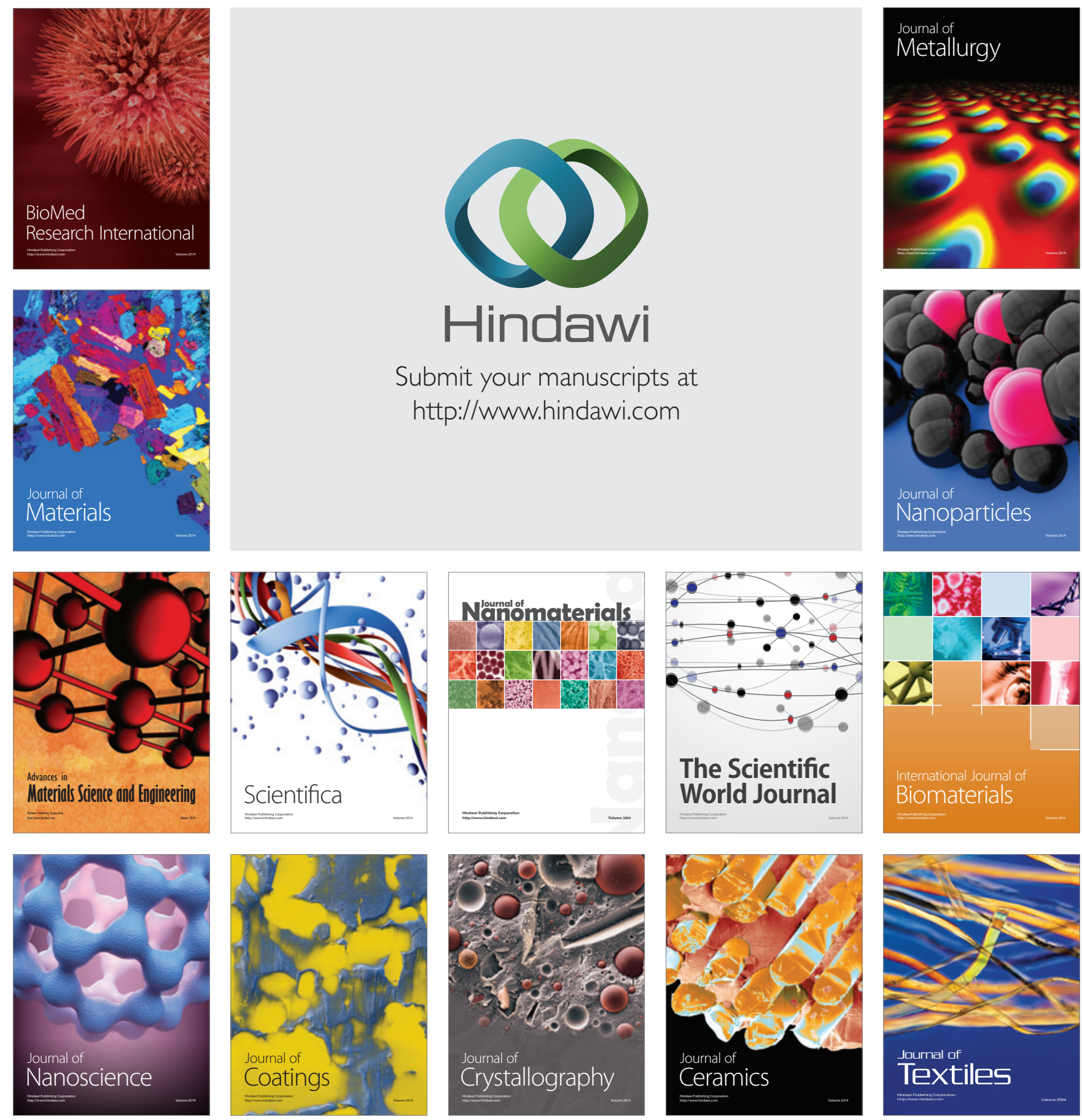